\title{
CRITICAS ACERCA DA EFETIVIDADE DO INSTITUTO DA COLABORAÇÃO PREMIADA: uma analise a partir do neoliberalismo
}

\section{Pedro Augusto Gomes Santiago Reis ${ }^{1}$}

\section{RESUMO}

As recentes movimentações jurisdicionais em matéria processual penal, geradas pela atuação das autoridades policiais e do Ministério Público no combate à criminalidade, o instituto da colaboração premiada ganhou destaque por estar presente em várias demandas envolvendo políticos do alto escalão. Contudo, a utilização deste instituto está, em muitos dos casos, sendo utilizado de maneira errônea, infringindo preceitos constitucionais e direitos fundamentais. Tudo isso, justifica-se pela influência do neoliberalismo na sistemática governamental do país, onde tudo é tratado como mercadoria negocial, inclusive direitos fundamentais, à justificativa de uma ilusória eficácia de combate à criminalidade.

Palavras-chave: Colaboração premiada; processo penal; efetividade; neoliberalismo; processo constitucional; ilegalidade.

\section{CRITICISM ABOUT THE EFFECTIVENESS OF THE INSTITUTE OF PLEA BARGAIN: an analysis based on neoliberalism}

\begin{abstract}
:
The recent jurisdictions in criminal procedural matters, generated by the actions of the police authorities and the Public Prosecutor's Office in the fight against crime, the institute of plea bargain was highlighted by being present in several demands involving politicians of high echelon. However, the use of this institute is in many cases being misused, violating constitutional precepts and fundamental rights. All this is justified by the influence of neoliberalism in the governmental system of the country, where everything is treated as a bargaining commodity, including fundamental rights, to the justification of an illusory effectiveness in fighting crime.
\end{abstract}

Keywords: Plea bargain; criminal proceedings; effectiveness; neoliberalism; constitutional process; illegality.

\section{INTRODUÇÃO}

\footnotetext{
${ }^{1}$ Advogado. Professor. Mestrando em Direito pela Universidade de Itauna. Pós-graduado em Ciências Penais pela Faculdade de Direito Milton Campos (2014). Graduado em Direito pela Pontifícia Universidade Católica de Minas Gerais (2011). E-mail: ppedroaugusto@gmail.com
}

Revista de Direito Penal, Processo Penal e Constituição | e-ISSN: 2526-0200 | Goiânia | v. 5 | n. 1 | p. 113 - 129 | Jan/Jun. 2019. 
Tem-se como objetivo principal neste trabalho, fazer uma analise quanto à efetividade da colaboração premiada e sua utilidade no processo judicial, analisando seus limites e sua legalidade a partir de um modelo constitucional e democrático de processo.

Este instituto vem sendo utilizado a inúmeros anos pelo direito comparado com diferentes nomeações, como é o caso da "plea bargaining" no direito norte-americano e da "crown witness" no direito inglês, ambos com a mesma função, beneficiar com redução de pena ou até mesmo o perdão judicial ao coautor que contribuir com a persecução penal.

Olhando para trás, temos emblemáticos acontecidos históricas envolvendo delações. No Império Romano, no intervalo aproximado entre 27 a.C. a 476 d. C., a delação se tornou complementar da persecução penal, passando a ser peça fundamental na atividade investigatória com a finalidade de identificar os autores de uma infração, as circunstâncias e as motivações do crime. Nos contos bíblicos, temos um episódio épico quando Judas Iscariotes delata a identidade de Jesus de Nazaré para o Império Romano em troca de trinta moedas de prata. (LEITE, 2018).

Cuida-se aqui de descrever sobre o instituto da colaboração premiada no sistema jurídico brasileiro à luz dos postulados fundamentais de direito penal e processual penal, de forma que a aplicação do instituto possa ser harmonizada com o ordenamento jurídico vigente, sobretudo a Constituição da República, identificando as principais questões de natureza prática a serem vencidas para que alcance seu objetivo com presteza e efetividade, sem atropelos às disposições constitucionais.

A problemática a ser enfrentada decorre da forma e das circunstâncias de como os acordos de colaboração premiada são realizados, partindo-se do principio que, em quase totalidade dos casos, há uma disparidade entre as partes processuais, onde o Estado, como polo mais forte, dita as regras do jogo a seu bel prazer, forçando o colaborador, em muita das vezes, a abrir mão de vários direitos constitucionais, como o de não se auto incriminar, por exemplo, a troco de uma benesse processual, tudo isso, influenciado pelo que chamamos de neoliberalismo, onde tudo é tratado como mercadoria negocial, inclusive valores de cunho moral, na finalidade de enaltecer o trabalho do Estado e passar uma falsa impressão para a sociedade de que a criminalidade está sendo combatida com presteza e efetividade. 
A hipótese científica que temos é de que a utilização deste instituto moldado pela Lei 12.850/13, com o Estado articulando as peças do jogo processual da forma que melhor the convém, de maneira ilimitada, caminha contramão daquilo que tanto buscamos, um estado democrático de direito, tornando este mecanismo processual inteiramente inconstitucional.

Em termos metodológicos, foi realizada uma pesquisa bibliográfica acerca dos assuntos relacionados diretamente ao tema, dentre elas livros e artigos acadêmicos publicados nas esferas do direito penal, processual penal, civil e constitucional, utilizando-se do método dedutivo para confirmação da hipótese no tocante à real efetividade e constitucionalidade da colaboração premiada.

\section{A CRIAÇÃO DA LEI 12.850/13 E SUA APLICAÇÃO}

Nosso ordenamento jurídico, no ano de 2013, recepcionou a Lei 12.850/13 que dispõe sobre as organizações criminosas, normatiza em um viés procedimental a colaboração premiada, momento em que este instituto ganhou maior status no âmbito processual penal, inclusive pelos atuais acontecimentos em nossa federação envolvendo diversos políticos de alto escalão, trazendo ainda a atenção da mídia.

Contudo, anteriormente, a Lei 8.072/90, que trata sobre os Crimes Hediondos, já instituía uma minorante para aquele que denunciar um dos participes de uma quadrilha à autoridade, porém, não especifica os requisitos para a validade dessa colaboração premiada, nem mesmo descreve seu procedimento.

Inicialmente cumpre fazer uma breve distinção entre as nomenclaturas "colaboração premiada" e "delação premiada". Muito se confunde os nomes no sentido de ser dito como a mesma coisa, o que, em regra, não é. O professor Luiz Flávio Gomes entende que:

Não se pode confundir delação premiada com colaboração premiada. Esta é mais abrangente. $\mathrm{O}$ colaborador da justiça pode assumir a culpa e não incriminar outras pessoas (nesse caso, é só colaborador). Pode, de outro lado, assumir a culpa (confessar) e delatar outras pessoas (nessa hipótese é que se fala em delação premiada). (GOMES, 2010) 
Em outras palavras, a delação premiada é uma das formas de colaboração com a justiça, ou seja, além de delatar, que segundo Guilherme de Souza Nucci (2007, p. 1024) "significa acusar ou denunciar alguém, no sentido processual, utilizando o termo quando um acusado, admitindo a prática criminosa, revela que outra pessoa também o ajudou de qualquer forma", pode o colaborador, colaborar de outras maneiras, quais sejam, explicando a operacionalidade de uma organização, informando detalhes de um esquema criminoso existente, indicando as vezes um local onde esteja alocado objetos de valores ou dinheiro em espécie que tenham ligação com a organização, dentre outras formas.

O desenvolvimento e a evolução do instituto da colaboração premiada, adveio, em tese, das dificuldades enfrentadas pelo Estado em combater o crime organizado, que é praticado mediante concurso de pessoas, apresentando registros desde a idade média com as Ordenações Filipinas na União Ibérica que vigorou de 1603 até a entrada em vigor do Código Criminal de 1830, conquistando um enfoque maior com a sofisticação da criminalidade. (CRUZ, 2006)

Com o passar do tempo, as armas utilizadas pelo Estado para combater o crime organizado foram ficando deficitárias, tornando-as ineficazes, momento em que a colaboração premiada surge com a finalidade de apresentar resultados práticos e efetivos, suprindo os déficits estatais.

A colaboração premiada é um instituto que tem o Ministério Público como ator principal e, é disciplinada a priori pelo artigo $4^{\circ}$ da Lei $12.850 / 13^{2}$, que dispõe, em seu caput, os tipos de benefício que podem ser concedidos, determinando uma efetividade na colaboração para que produza resultados de forma eficiente e voluntária, não podendo incorrer qualquer tipo de coação, seja ela moral ou física.

A colaboração premiada consiste em um meio de obtenção de prova utilizado na fase investigatória, considerada um contrato em que por meio da confissão e indicação de

\footnotetext{
${ }^{2}$ Art. $4^{4^{\circ}}$ - O juiz poderá, a requerimento das partes, conceder o perdão judicial, reduzir em até $2 / 3$ (dois terços) a pena privativa de liberdade ou substituí-la por restritiva de direitos daquele que tenha colaborado efetiva e voluntariamente com a investigação e com o processo criminal, desde que dessa colaboração advenha um ou mais dos seguintes resultados:
} 
coautores e partícipes o réu auxilia na investigação em troca de diminuição de pena e inclusive possível perdão judicial, tudo isso realizado mediante um acordo reduzido a termo entre réu e Estado, ocasionando em um negócio jurídico processual.

O professor Renato Brasileiro de Lima define colaboração premiada como sendo:

“[...] uma técnica especial de investigação por meio da qual o coautor e/ou partícipe da infração penal, além de confessar seu envolvimento no fato delituoso, fornece aos órgãos responsáveis pela persecução penal informações objetivamente eficazes para a consecução de um dos objetivos previstos em lei, recebendo, em contrapartida, determinado prêmio legal" (LIMA, 2014, p. 728-729).

Contudo, para a validade desta colaboração, deve o colaborador estar acompanhado de um procurador particular ou defensor público, bem como estar voluntariamente naquela posição, tudo isso sem a participação do Julgador ${ }^{3}$. Sendo assim, após o depoimento, o contrato é assinado entre as partes (Ministério Publico e acusado) e encaminhado ao Magistrado para sua homologação, lembrando que este, para homologar o termo, não analisa o mérito do que foi dito, nem o mérito das provas, ou seja, ele não vai dizer se o que o colaborador disse é verdadeiro ou falso, será analisado apenas os elementos formais do contrato, a voluntariedade, a regularidade e a legalidade daquele acordo ${ }^{4}$ para que, no momento da decisão, seja analisada sua eficácia ${ }^{5}$.

Importante frisar que, o Estado, órgão que tecnicamente coordena os agentes públicos envolvidos em um acordo de colaboração, deve prezar pela constitucionalidade daquele ato, respeitando os direitos e garantias fundamentais do colaborador. Neste sentido, a professora Gisele Leite diz:

[...] o Estado ao investigar deverá manter uma postura ética e responsável a fim de inspirar os seus agentes a agirem em conformidade com a lei maior

\footnotetext{
${ }^{3}$ Art. $4^{\circ}, \S 6^{\circ}$ O juiz não participará das negociações realizadas entre as partes para a formalização do acordo de colaboração, que ocorrerá entre o delegado de polícia, o investigado e o defensor, com a manifestação do Ministério Público, ou, conforme o caso, entre o Ministério Público e o investigado ou acusado e seu defensor.

${ }^{4}$ Art. $4^{\circ} \S 7^{\circ}$ Realizado o acordo na forma do $\S 6^{\circ}$, o respectivo termo, acompanhado das declarações do colaborador e de cópia da investigação, será remetido ao juiz para homologação, o qual deverá verificar sua regularidade, legalidade e voluntariedade, podendo para este fim, sigilosamente, ouvir o colaborador, na presença de seu defensor

${ }^{5}$ Art. $4^{\text {o }} \S 11$. A sentença apreciará os termos do acordo homologado e sua eficácia
}

Revista de Direito Penal, Processo Penal e Constituição | e-ISSN: 2526-0200 | Goiânia | v. 5 | n. 1 | p. 113 - 129 | Jan/Jun. 2019. 
respeitando-se, sempre, as garantias fundamentais, ou seja, a colaboração há que se sempre obtida de forma livre e espontânea sem haver qualquer espécie de coação. Nem mesmo com o prolongamento desnecessário de medidas constritivas de liberdade: temporária e preventiva. (LEITE, 2018).

Contudo, na realidade prática dos atuais acordos de colaboração realizados, as coisas não andam de forma tão linear assim. Como veremos no discorrer do texto, muitas ilegalidades vem sendo cometidas na utilização deste mecanismo por vários motivos, aqui levantaremos dois deles: ineficácia normativa e influência neoliberal.

\section{A INFLUÊNCIA DO NEOLIBERALISMO E A EFETIVIDADE DA COLABORAÇÃO PREMIADA.}

Para adentrar na discussão da efetividade e dos reflexos processuais da colaboração premiada, impossível não analisar a questão ética deste instituto. Quando um colaborador delata algum comparsa, membro da organização criminosa, para fazer uso do prêmio oferecido pelo Estado, subjetivamente entende-se que foi traída a confiança entre estes e isso pode acarretar em futuros acontecimentos nada agradáveis, uma vez que a importância da confiança transcende a esfera das relações privadas e atinge todo o corpo social, inserindo-se no âmbito do interesse público.

Vale mencionar que é indubitável a estreita ligação entre a delação e o espírito antidemocrático, visto que na Alemanha nazista, os alemães recebiam de 2 a 3 mil delações por dia, destinadas a expor a origem judaica de compatriotas e os hábitos subversivos de alguns indivíduos, bem como no governo ditatorial do Brasil, marcado por inúmeras prisões efetuadas com base em denúncias infundadas feitas ao Departamento de Ordem Política e Social. (CRUZ, 2006).

O neoliberalismo, identificado por Michel Foucault (apud BRITO, 2016, p. 35), como "uma nova arte de governar que começou a ser formulada, pensada e desenhada mais ou menos em meados do século XVIII" é a maneira de exercer uma governança, governando o quanto menos possível, de modo que a razão de Estado agora estará diretamente conectada à economia política. Neste viés, o mercado então passa a dizer o que é verdade, devendo-se, nas palavras de Foucault (apud BRITO, 2016, p. 36) “deixa-lo agir com o mínimo possível de 
intervenção, justamente para que ele possa formular a sua verdade e propô-la como regra e norma à pratica governamental", 6

A professora e doutrinadora Michelle Barbosa de Brito escreve:

"O mercado diz a verdade sobre como um bom governo deve agir, e é com base nessa verdade que serão tomados os rumos de uma sociedade nos mais diversos setores (politico, legislativo, judicial). O modelo Neoliberal passou a estabelecer as regras do jogo, compondo o conteúdo silencioso do discurso punitivo. Os custos sociais decorrentes da logica neoliberal são inquestionáveis, assim como o papel que o Direito Penal passou a exercer nesse sistema. Diante de um regime que relegou a segundo plano o cumprimento das obrigações positivas do Estado, o Direito Penal começou a ser utilizado como um mecanismo de controle social da população marginalizada por esse regime". (BRITO, 2016, p. 36)

Infelizmente, hoje no Brasil, tudo é tratado como mercadoria, os valores passaram a ser tratados como mercadorias, não diferente a colaboração premiada que de fato, é uma mercadoria, sendo que o próprio nome "colaboração" já reflete uma ideia de "venda", bem como, a própria etimologia da expressão "colaboração espontânea", verifica-se a tentativa do legislador de diluir a presada tradição da palavra "traição" e pior, premiar o que inicialmente soa como abjeto (SANTOS, 2016, p. 3). Como bem escreve o magistrado Rubens Casara (2017) "a delação na verdade é chamada de colaboração para disfarçar o "desvalor" ético inerente a todo e qualquer delator, com a delação premiada, o Estado perde a superioridade ética que deveria o distinguir do criminoso" $"$.

\footnotetext{
${ }^{6}$ A razão neoliberal levou à superação do Estado Democrático de Direito. Foi a razão neoliberal, ao buscar o lucro ilimitado, que levou à percepção dos direitos e garantias fundamentais como obstáculos à eficiência do Estado e do Mercado.

No Estado Pós-Democrático, desaparece a dimensão substancial da democracia (e mesmo a regra da maioria torna-se descartável). Se o Estado Democrático de Direito se caracterizava pela existência de limites rígidos ao exercício do poder, de qualquer poder, no Estado Pós-Democrático, em que o único objetivo é o aumento do Capital, inexistem limites rígidos ao exercício do poder. Mas, não é só. No Estado Pós-Democrático, que surge em atenção à razão neoliberal, o poder político cada vez mais se identifica com o poder econômico. (CESARA, 2017)
}

\footnotetext{
${ }^{7}$ No Estado Pós-Democrático, desaparece a dimensão substancial da democracia (e mesmo a regra da maioria torna-se descartável). Se o Estado Democrático de Direito se caracterizava pela existência de limites rígidos ao exercício do poder, de qualquer poder, no Estado Pós-Democrático, em que o único objetivo é o aumento do Capital, inexistem limites rígidos ao exercício do poder. Mas, não é só. No Estado Pós-Democrático, que surge em atenção à razão neoliberal, o poder político cada vez mais se identifica com o poder econômico (CESARA, 2017)
} 
Neste mesmo segmento neoliberal, para explicar a falta de critérios relacionado ao modo como fora realizados alguns recentes acordos de colaboração premiada ligados a operação Lava Jato, o magistrado e doutrinador Alexandre Morais da Rosa vai dizer:

"[...] para além da legalidade, a metodologia utilizada difere em cada comprador, dada a ausência de regramento legal do "modo" como a negociação deve acontecer. Prevalece o jogo da negociação, do mercado flutuante e da capacidade de compra e venda de informações probatórias" (ROSA, 2016).

$\mathrm{O}$ atual circo político brasileiro, trazido a tona pela mídia, vive um momento delicado, que está sendo transparecido à sociedade através do poder judiciário. Não estou aqui defendendo os acusados envolvidos nessa massa delituosa, mas não se pode compactuar com os atos de um Ministério Público que, erroneamente, tem poderes plenos e ilimitados para negociar e articular os mecanismos processuais, a ponto de ameaçar e pressionar os investigados dizendo: "se você não delatar, irá sofrer a mais dura e severa punição, mas se você delatar, irá usufruir de muitas benesses", sem contar que utiliza-se ainda a prisão cautelar como instrumento de tortura para forçar a delação, sob a justificativa de que

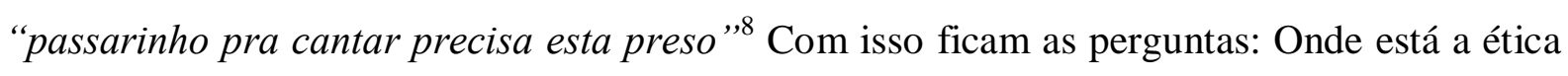
por parte do Estado? Onde está a voluntariedade por parte do colaborador? Onde estão os limites para a atuação do Estado?

Como bem diz Aury Lopes Junior e Alexandre Morais da Rosa (2015) "a superioridade do acusador público, acrescida do poder de transigir, faz com que as pressões psicológicas e as coações sejam uma pratica normal, para compelir o acusado a aceitar o acordo e também a "segurança" do mal menor de admitir uma culta, ainda que inexistente".

O magistrado Rubens Casara escreve que:

"A razão neoliberal constrói uma visão de mundo que reduz as complexidades e que aposta em construções discursivas vendidas como

\footnotetext{
${ }^{8}$ Em parecer do Ministério Público Federal no ano de 2014 sobre a operação Lava Jato, o procurador Manoel Pastana disse que o Direito precisa evoluir e que a figura da delação premiada é recente no Direito Penal brasileiro. Por isso, diante de uma regra que fala da conveniência da instrução de forma abstrata como causa para a prisão preventiva, é possível se interpretar que uma dessas conveniências seja forçar o réu a colaborar, dizendo ainda que: "Em crime de colarinho branco, onde existem rastros mas as pegadas não ficam, são necessárias pessoas envolvidas com o esquema para colaborar. E o passarinho pra cantar precisa estar preso". Disponível em: < https://www.conjur.com.br/2014-nov-27/parecer-mpf-defende-prisoes-preventivas-forcar-confissoes>.
}

Revista de Direito Penal, Processo Penal e Constituição | e-ISSN: 2526-0200 | Goiânia | v. 5 | n. 1 | p. 113 - 129 | Jan/Jun. 2019. 
positividades (pós-verdade). A realidade, complexa, é formada tanto por positividades quanto por negatividades. A informação a ser negociada, ao contrário, é pura positividade, é aquilo que se quer ouvir. [...] a informação "obtida" nas delações premiadas, muitas vezes obtidas após prisões e coações ilegítimas, em um quadro no qual direitos e garantias fundamentais estão afastados em nome da lógica neoliberal, não guarda qualquer relação necessária com a verdade. Trata-se de um mero negócio no qual o valor "verdade" também é descartável enquanto o significante "verdade" passa a ser manipulado" (CASARA, 2017)

Esta pressão antidemocrática exercida pelo Estado, disposto a constranger e obter o pacto a qualquer preço (LOPES JR, MORAIS, 2015) causa um reflexo extremamente negativo, onde, por muita das vezes o acusado utiliza-se de uma "pseudo colaboração" dizendo inverdades sobre crimes que não conheceram, delatando pessoas que nada tem haver com os fatos, por medo de uma punição rigorosa e excessiva.

Não é de difícil percepção que o instituto da colaboração premiada vem sendo aplicado no Brasil como uma espécie de justiça negociada ou justiça mercantilizada na ideia de apresentar resultados de forma célere e econômica, tudo isso fomentado pela ausência de uma legislação sólida, acarretando em inúmeras atrocidades processuais aos olhares de um processo constitucional. Neste viés, Aury Lopes Junior vai dizer:

"A justiça negociada está atrelada à ideia de eficiência (viés economicista), de modo que as ações desenvolvidas devem ser eficientes para com isso chegarmos a um melhor resultado. O Resultado deve ser visto no contexto de exclusão (social e penal). O indivíduo já excluído socialmente (por isso desviante) deve ser objeto de uma ação efetiva para obter-se o (máximo e certo) apenamento, que corresponde à declaração de exclusão jurídica. Se acrescentarmos a esse quadro o fator tempo - tão importante no controle da produção, até porque o deus-mercado não pode esperar -, a eficiência passa a ser mais uma manifestação (senão sinônimo) de exclusão" (LOPES JR, 2006, p. 141)

A partir do momento em que a concepção neoliberalista foi irradiada, abarcada como uma "nova razão de mundo", os valores morais e os princípios éticos que antes condicionavam a atuação dos sujeitos em suas relações tanto privadas quanto públicas, tornaram-se negociáveis e, portanto, descartáveis. 
Infelizmente, temos que dizer que a famosa "operação Lava Jato", comandada pelos representantes do Estado, não passa de um grande produto negocial, encostando de lado a garantia de um processo penal constitucional e dando dimensão ao entretenimento midiático.

\section{AS ILEGALIDADES E INCONSTITUCIONALIDADES PROCESSUAIS EXISTENTES NA PRATICA DOS ACORDOS DE COLABORAÇÃO PREMIADA}

Varias atrocidades processuais vem sendo catalogadas nos acordos de colaboração premiada, a primeira delas está relacionada às clausulas contratuais e os "prêmios" oferecidos no contrato de colaboração premiada.

Estão havendo inúmeras clausulas ilegais estipuladas pelo Ministério Público que vão além de sua competência, como a fixação de penas (atributo conferido ao juiz) bem como a imposição de restrição a condutas meramente morais. Constitucionalmente falando, não se pode o Ministério Público, representado por um cidadão na figura do Procurador da República, ter esse poder negocial atuando como um legislador, pois o material humano brasileiro está eivado de vestígios inquisitoriais que o torna um soberano inquisidor e antidemocrático. ${ }^{9}$

$\mathrm{O}$ argumento utilizado pelo Estado para a justificativa da utilização do instituto de colaboração premiada, que é a sofisticação e a evolução organizacional do crime organizado, apenas serve para ludibriar a sociedade, onde na verdade o que ocorreu foi uma má gestão estatal ao longo dos anos passados, concluindo que, não foi o crime que se "organizou" e sim o Estado que se "desorganizou".

Outra inconstitucionalidade está ligada ao principio do contraditório, que é, em quase a totalidade dos casos, violado pelo fato de as partes negociantes estarem em plena posição de

\footnotetext{
${ }^{9} \mathrm{O}$ processo penal brasileiro, não dispõe sobre regimes de prisão de forma diferenciada ou específica, os regimes são: aberto, semiaberto ou fechado, inexistindo a modalidade de "regime semiaberto diferenciado". "[...] foi noticiada uma sentença penal condenatória na operação "lava jato" em que alguém - beneficiado pela delação premiada (ou seja, pena negociada) - é condenado a 15 anos e 10 meses em regime de "reclusão doméstica" ou "prisão domiciliar". Depois vem um regime "semiaberto diferenciado" (??) e uma progressão para o regime aberto após dois anos. Tudo isso sob o olhar atônito do Código Penal, que não se reconhece nessa "execução penal a la carte" (LOPES JR, MORAIS, 2015).
}

Revista de Direito Penal, Processo Penal e Constituição | e-ISSN: 2526-0200 | Goiânia | v. 5 | n. 1 | p. 113 - 129 | Jan/Jun. 2019. 
desigualdade, tendo em vista os amplos e irrestritos poderes conferidos ao Estado. Neste sentido Aury Lopes Jr. vai dizer:

"[...] o que caracteriza o princípio do contraditório é exatamente o confronto claro, público e antagônico entre as partes em igualdade de condições. Essa importante conquista da evolução do Estado democrático de Direito resulta ser a primeira vítima da justiça negociada, que começa a sacrificar o contraditório e por matar a igualdade de armas. Que igualdade pode existir na relação do cidadão suspeito frente à prepotência da acusação, que, ao dispor do poder de negociar, humilha e impõe suas condições e estipula o preço negócio?" (LOPES JR, 2006, p. 143).

Infelizmente, não é preciso muito esforço para encontrar semelhanças entre a colaboração premiada no Brasil e o sistema inquisitorial que perdurou com mais veemência na Europa durante a Idade Média, marcado pelo autoritarismo Estatal que, buscava a verdade mediante tortura aos acusados, assumido as funções de acusar e julgar como bem entender utilizando-se de seu subjetivismo. ${ }^{10}$

$\mathrm{Na}$ colaboração premiada, a pretexto de combater a criminalidade e alcançar a segurança pública, imprimindo maior eficiência ao processo penal, busca-se a "verdade" por meio de confissão do réu e da delação de co-autores ou partícipes, mediante a concessão de "premio" ao delator. No procedimento inquisitório, a pretexto de combater a propagação de condutas heréticas, buscava-se obsessivamente a "verdade" por meio da confissão mediante o recurso da tortura. (BRITO, 2016, p. 63). Em simples observância, é fácil perceber a semelhança entre eles, claro que, reconhecendo as diferenças entre os métodos de tortura daquela época e da atualidade, pois, prender e exercer pressão psicológica simplesmente para que o colaborador fale algo, é um mecanismo de tortura. Na prática, ocorre da forma como o professor e jurista Abraão Soares dos Santos explica:

“[...] as condições do delator lhe são completamente desfavoráveis: mesmo que não esteja sofrendo coação física como manda a tradição nacional, sua situação mental não comporta outros prolongamentos do que salvar a si

\footnotetext{
${ }^{10}$ Em 1229, o Papa Gregório IX criou o Tribunal da Inquisição ou Santo Oficio, que era um tribunal eclesiástico responsável pela investigação e pelo julgamento daqueles que cometiam heresia. No sistema inquisitório, o órgão judicante acumulava as funções de acusar e de julgar. O processo inquisitório era norteado pela busca obsessiva da verdade, cuja prova fundamental assentava-se na confissão, obtida quase sempre por meio da tortura. Assim, o saber do acusado era a principal fonte de informação, seus direitos eram ignorados para que a realidade preconstituída fosse confirmada. A "verdade" já estava definida; o processo só precisava confirmar a verdade estabelecida pela acusação. (BRITO, 2016, p. 63)
}

Revista de Direito Penal, Processo Penal e Constituição | e-ISSN: 2526-0200 | Goiânia | v. 5 | n. 1 | p. 113 - 129 | Jan/Jun. 2019. 
próprio, ditado pelo instinto de sobrevivência numa sociedade cada vez mais individualista. Ora, se um indivíduo que não seja um 'cliente' comum do Direito Penal como os próprios diplomas legais apontam, se vê algemado, de 'macacão' amarelo e em depoimento secreto: 'Dá uma vontade danada de trair' (SANTOS, 2016, p. 5)

De fato, a legislação brasileira é completamente omissa em disciplinar o modus operandi a ser observado na celebração deste "acordo processual". Com efeito, num primeiro momento, o próprio Ministério Público Federal declarou na mídia que os investigados "eram presos para forçar a delação" "11, fato este que não condiz com o requisito da liberdade e da voluntariedade em delatar. Trata-se a rigor de uma refinada tortura psicológica, pois os investigados presos preventivamente, já sem forças e sem esperanças e, vendo resultados favoráveis de outros delatores, acabam "decidindo" também delatar alguém para minimizar sua condenação certa, tudo isso tornando o instituto cada vez mais ineficiente e com resultados ineficazes. (BITENCOURT, 2017). Neste liame, O professor Pierpaolo Cruz Bottini afirma:

“[...] gostemos ou não, a delação é um instrumento legitimado pelo legislador, mas a falta de regulação precisa dificulta sua aplicação e acaba por ensejar incidentes que retardam o processo penal e não raro desaguam em sua nulidade completa, razão pela qual parece adequado um labor legislativo para apurar seu procedimento e seus contornos" (BOTTINI, 2012).

Patente é que a legislação brasileira não estabelece nenhum regramento de ordem processual para a colaboração premiada, o que cria dificuldades principalmente quanto ao procedimento a ser utilizado e à valoração probatória das declarações daqueles que colaboram com a Justiça, ficando a dúvida se tais declarações podem, por si só, desvirtuar o estado constitucional de inocência do colaborador acusado.

Um dos requisitos, fundamentais e indispensável para a validade e legitimidade de um acordo de colaboração é a liberdade e a voluntariedade do colaborador que, na maioria das vezes, não estão presentes, tendo em vista que colaboradores presos, encarcerados, amedrontados, psicológica e fisicamente fragilizados, estão realizando acordos com o

\footnotetext{
${ }^{11}$ Segundo informações que circulam na imprensa, os delatores têm prestado dezenas de depoimentos (vazou na mídia que o tal de Cerveró foi interrogado 37 vezes ao longo de dias e dias, quiçá de meses à disposição dos investigadores oficiais). Disponível em: <https://www.conjur.com.br/2017-jun-10/cezar-bitencourt-delacaopremiada-favor-legal-antietico\#_ftn3>
} 
Ministério Público. Trata-se, a rigor, de uma refinada tortura psicológica, pois os investigados, presos preventivamente em um sistema carcerário precário, já sem forças e sem esperanças, e vendo resultados favoráveis de outros delatores, acabam "escolhendo" também delatar alguém para minimizar sua já premeditada condenação.

Outro ponto a ser criticado e debatido é no tocante às renunciais de direitos fundamentais havida em alguns acordos de colaboração premiada no âmbito da "operação lava jato”. No acordo realizado entre o Ministério Público Federal e Paulo Roberto Costa, há uma clausula expressa onde o Réu renuncia aos seus direitos processuais, desistindo dos habeas corpus impetrados, se comprometendo ainda a não discutir questões de competências e nulidades processuais. ${ }^{12}$

A dúvida que perdura é no tocante à possibilidade de renunciar a tais direitos, seria possível, acusação e defesa renunciarem a estes direitos? Estariam estas matérias no escopo da discricionariedade do colaborador?

É sabido que qualquer ato jurídico praticado por magistrado incompetente é um ato nulo de pleno direito. Essa é a regra, portanto, como acordar em não discutir questões de competência e nulidades processuais se estes erros invalidam aquele ato? Para melhor explicar essa matéria, Aury Lopes Junior vai dizer:

"Como regra das nulidades absolutas, a gravidade da atipicidade processual conduz à anulação do ato, independentemente de qualquer alegação da parte interessada, podendo ser reconhecida de ofício pelo juiz ou em qualquer grau de jurisdição. Sendo alegada pela parte, não necessita demonstração do prejuízo, pois manifesto ou presumido, como preferem alguns. Os exemplos costumam conduzir à violação de princípios constitucionais, especialmente o direito de defesa e o contraditório. Nessa linha, é nulo o processo sem defensor; a ausência de alegações finais (ou dos debates orais); quando ocorre colidência de teses entre réus diferentes, mas com um mesmo advogado; a perícia feita por um único perito não oficial etc. Também entra no campo das nulidades absolutas a sentença (e todos os atos) proferida por

\footnotetext{
${ }^{12}$ Cláusula 12 do acordo de colaboração premiada de Paulo Roberto Costa pela "lava jato". A defesa desistirá de todos os habeas corpus impetrados no prazo de 48 horas, desistindo também do exercício de defesas processuais, inclusive de discussões sobre competência e nulidades. Disponível em: <https://www.conjur.com.br/dl/lava-jatoacordo-delacao-paulo-roberto.pdf>. Acesso em 10 de Abril de 2019.
}

Revista de Direito Penal, Processo Penal e Constituição | e-ISSN: 2526-0200 | Goiânia | v. 5 | n. 1 | p. 113 - 129 | Jan/Jun. 2019. 
juiz absolutamente incompetente, como vimos no estudo da competência" (LOPES JR, 2013, p. 1136-1137).

Por fim, após todo o estudo e abarcando de forma geral o instituto da colaboração, impreterível deixar de citar uma passagem categórica do magistrado Alexandre Morais da Rosa, onde afirma que o atual estágio da colaboração torna um mecanismo de terror e surpresa:

"[...] Talvez se possa entender um pouco mais sobre os dilemas contemporâneos do processo penal eficiente via delação premiada, quer para aderir, quer para rejeitar. $O$ que não se pode é continuar aceitando as -novidadesll legislativas sem uma profunda reflexão de qual é o nosso papel, nem os efeitos que nossas posições podem engendrar no coletivo. 63 Os limites democráticos precisam ser recompostos. $\mathrm{O}$-tubarão já foi preso, morto, esquartejado, mas sempre surge o medo de que ele retorne, não porque o quer, mas porque o - tubarão habita o mais íntimo do humano. Surpresa? Medo? Angústia? Tudo humano, demasiadamente humano, diria Nietzsche. Quem sabe entendendo se possa aliviar a surpresa, o medo e a angústia, embora não tenha tanta certeza!" (ROSA, 2011, p. 11).

\section{CONSIDERAÇÕES FINAIS}

Cediço dizer que a colaboração premiada atualmente, demonstra ser um instrumento utilizado no combate a infrações cometidas em concurso de pessoas ou quadrilhas, não só no Brasil como no mundo todo, porém, a legislação brasileira é falha ao não dispor com clareza seus procedimentos, e com isso, demonstra relativizar garantias constitucionais mediante intimidação pela isenção de um sistema penal falido. Essas características nos remetem a concluir que a colaboração premiada é uma forma do Estado forçar, a todo custo, uma delação e até mesmo uma confissão.

De fato, temos que a realidade de um acordo de colaboração premiada é complexa, o que torna necessário uma densa elaboração legislativa, sob pena de permitir-se várias ofensas às garantias do colaborador e dos demais delatados envolvidos, podendo ferir de forma inaceitável a tutela da dignidade humana, valor este que deve representar uma barreira intransponível.

Revista de Direito Penal, Processo Penal e Constituição | e-ISSN: 2526-0200 | Goiânia | v. 5 | n. 1 | p. 113 - 129 | Jan/Jun. 2019. 
Precisamos urgentemente de uma lei específica, somente para colaboração premiada que unifique os diferentes dispositivos existentes, precisamos de uma lei que discipline os limites da delação, especificando ainda o que pode fazer e principalmente, que deixe claro, o que não se pode fazer na utilização deste instituto, tendo em vista que o que se vê atualmente no Brasil são excessos desta pratica negocial, tudo isso porque a atual legislação disciplinadora, Lei 12.850/13 sofre de carência e insuficiência normativa, abrindo um espaço para que o Ministério Público, juntamente com a conivência de alguns Magistrados atue de forma inquisitorial e soberana, o que vai de contra ao modelo constitucional e democrático de processo.

Busca-se, a todo momento, um processo penal eficiente que compactue com o sistema acusatório avocado pela nossa Carta Magna para que produzam resultados eficazes, para que tragam decisões justas e acertadas. A colaboração premiada como vem sendo utilizada em nosso ordenamento, destoa muito deste objetivo, uma vez que, essas atrocidades movimentam a maquina judiciária de forma ineficiente, refletindo, muita das vezes, em decisões equivocadas e ineficazes.

Deixamos claro que não somos contra a colaboração premiada, criticar este instituto, não é fazer um manifesto à impunidade, muito pelo contrário, digamos com veemência que é um instituto processual muito importante no nosso ordenamento jurídico, porém, deve-se respeitar as regras do jogo. O Ministério Público, infelizmente está se avocando em um poder soberano para alem dos seus limites de atuação e isso não é democrático. Punir é necessário, é um ato civilizatório, mas é preciso respeitar as regras para que não torne nosso processo ainda mais inconstitucional e repleto de ilegalidades, se é que assim já não está.

\section{REFERÊNCIAS.}


BITENCOURT, Cezar Roberto. Delação Premiada é favor legal, mas antiético. Disponível em: < https://www.conjur.com.br/2017-jun-10/cezar-bitencourt-delacao-premiada-favorlegal-antietico\#_ftn3>. Acesso em 01 de Abril de 2019

BRASIL, Constituição da República Federativa do Brasil de 1988. Disponível em <http://www.planalto.gov.br/ccivil_03/constituicao/constituicao.htm>. Acesso em 01 de Abril de 2019.

BRASIL, Lei $\mathrm{N}^{\mathrm{o}}$ 8.072, de 25 de Julho de 1990. Disponível em <http://www.planalto.gov.br/ccivil_03/leis/L8072.htm>. Acesso em 30 de Março de 2019.

BRASIL, Lei $\mathrm{N}^{\mathrm{o}}$ 12.850, de 02 de agosto de 2013. Disponível em < http://www.planalto.gov.br/ccivil_03/_ato2011-2014/2013/lei/112850.htm> Acesso em 30 de Março de 2019.

BRITO, Michelle Barbosa. Delação Premiada E Decisão Penal: Da Eficiência À Integridade. Belo Horizonte: Editora D'Plácido, 2016.

CANARIO, Pedro. Em parecer, MPF defende prisões preventivas para forçar réus a confessar. Consultor Jurídico. Disponivel em: <https://www.conjur.com.br/2014-nov27/parecer-mpf-defende-prisoes-preventivas-forcar-confissoes>. Acesso em 02 de Abril de 2019.

CASARA, Rubens. Delação premiada: mercadoria do Estado Pós-Democrático. Disponível em: <http://justificando.cartacapital.com.br/2017/09/16/delacao-premiada-mercadoria-doestado-pos-democratico/>. Acesso em 23 de Março de 2019.

CRUZ, André Gonzalez. Delação premiada. In: Âmbito Jurídico, Rio Grande, IX, n. 32, ago 2006. Disponível em: <http://www.ambitojuridico.com.br/site/index.php?n_link=revista_artigos_leitura\&artigo_id=3324>. Acesso em 30 de Março de 2019.

FOUCAULT, Michel. Nascimento da Biopolítica. São Paulo: Martins Fontes, 2008.

LIMA, Renato Brasileiro de. Manual de Processo Penal. 2. ed. rev. ampl. e atual. Salvador, JusPODIVM, 2014.

LOPES JR, Aury. Direito processual penal. 10 ed. São Paulo: Saraiva, 2013

LOPES JR, Aury. Introdução Crítica ao Processo Penal. Rio de Janeiro: Lúmen Júris, 2006

LOPES JR, Aury; ROSA, Alexandre Morais da. Com delação premiada e pena negociada, Direito Penal também é lavado a jato. Consultor Jurídico, v. 24, 2015. Disponível em: < https://www.conjur.com.br/2015-jul-24/limite-penal-delacao-premiada-direito-penal-tambemlavado-jato>. Acesso em 12 de Abril de 2019. 
GOMES, Luiz Flávio. Justiça Colaborativa e Delação Premiada. Disponível em: <https://lfg.jusbrasil.com.br/noticias/2108608/justica-colaborativa-e-delacao-premiada> Acesso em 01 de Abril de 2019.

GOMES, Luiz Flavio. Coordenador e autor responsável. Lei de drogas comentada. $3^{\text {a }}$ ed. São Paulo: RT, 2008.

LEITE, Gisele. Considerações sobre a colaboração premiada no processo penal brasileiro. Jornal Jurid, 2018. Disponível em: <https://www.jornaljurid.com.br/colunas/giseleleite/consideracoes-sobre-a-colaboracao-premiada-no-processo-penal-brasileiro>. Acesso em 27 de Março de 2019.

MINISTÉRIO PÚBLICO FEDERAL. Procuradora da República no Estado do Paraná. Termo de Acordo de Colaboração Premiada realizado entre Ministério Público Federal e Paulo Roberto Costa. Disponível em: <https://www.conjur.com.br/dl/lava-jato-acordo-delacaopaulo-roberto.pdf $>$. Acesso em 10 de Abril de 2019.

NUCCI, Guilherme de Souza. Código Penal Comentado. 7 ed. rev. atual. e ampl. São Paulo: RT. 2007.

POLI, Camilin Marcie de. Sistemas processuais penais. Empório do direito, Florianópolis, 2016

ROSA, Alexandre Morais da. Como funciona o mercado oculto da delação premiada. Consultor Juridico. 2016. Disponível em: <https://www.conjur.com.br/2016-nov-18/limitepenal-funciona-mercado-oculto-delacao-premiada>. Acesso em 28 de Março de 2019.

ROSA, Alexandre Morais da. Delação Premiada: Terror e Surpresa. In: Boletim Informativo do IBRAPP, n. 1, 2011/02, p. 10-11

ROSSETTO, Enio Luiz. A confissão no processo penal. São Paulo: Atlas, 2001.

SANTOS, Abraão Soares dos. A delação premiada no contexto de uma sociedade complexa: riscos e condições de possibilidades na democracia brasileira. 2016. Disponível em: < http://egov.ufsc.br/portal/sites/default/files/anexos/13474-13475-1-PB.pdf >. Acesso em 03 de Abril de 2019.

TÁVORA, Nestor. Curso de Direito Processual Penal. 10ª . ed. Bahia: JusPodivm, 2015. 